\title{
Correction: A qualitative investigation of medical students' attitudes to collusion in end of life care
}

Finch W, Gilhespy A, Christopher C et al. A qualitative investigation of medical students' attitudes to collusion in end of life care. BMJ Supportive \& Palliative Care 2017;7(Supp 2):A18.

The order of the authors has been corrected to Willow Finch, Sophie Holmes, Alex Gilhespy, Cecily Christopher.

(C) Article author(s) (or their employer(s) unless otherwise stated in the text of the article) 2018. All rights reserved. No commercial use is permitted unless otherwise expressly granted.

BMJ Supportive 2018;8:116. doi:10.1136/bmjspcare-2017-hospice.50corr1

A) Check for updates 